\title{
Corporate Environmental Responsibility with special reference to Toyota Motor Corporation
}

\author{
B. Lavanya ${ }^{1}$, Dr. M.Anbalagan ${ }^{2}$ \\ 1(Assistant Professor, Department of Commerce, Auxilium College, Thiruvalluvar University, Vellore, India) \\ 2(Associate Professor and Head, Department of Commerce, Voorhees College, Vellore, India)
}

\begin{abstract}
Today, companies have accepted their responsibility to do no harm to the environment. In this aspect, Corporate Environmental Responsibility is an integral part of corporate social responsibility and encompasses environmental commitment and awareness, stakeholder engagement, measuring, reporting and auditing, transparency, commitment to continuous improvement and going beyond compliance. In many developed nations, environmental protection agencies have come up with stringent regulations relating to the accounting and disclosures of environmental issues and measurement of cost of environmental degradation. This paper attempts to describe the initiatives taken by Toyota Motor Limited for making the environment clean and green with its objective of establishing low carbon society, establishing a recycling- based society, providing environmental protection and establishing a society in harmony and nature.
\end{abstract}

Keywords: Corporate Environmental Responsibility, Environmental protection, Low carbon society, recycling.

\section{Introduction}

Generally, the goal of most businesses is to run an efficient company while earning a profit. But now the traditional goal has been changed. Most of the companies of today started to perform the environmental friendly activities too. By running a good business and incorporating it with environment friendly policies, the company can win the hearts of many consumers. Lyon \& Maxwell (2007) define Corporate Environmental Responsibility as "environmentally friendly actions not required by law, also referred to as going beyond compliance, the private provision of public goods, or voluntarily internalizing externalities."

There are several ways to enhance a business. Firstly, to state a plan of how the company will work toward being environmentally friendly. Then it can use an environmental audit to make sure these goals are happening. One way businesses can promote the environment is to control odour, fumes, and vapors. The other ways a business can protect the environment by spill containment, the removal of heavy metals, installing heat recovery systems, promoting mist and smoke control, oxidation, and the recycling of items. The process of recycling can reduce pollution and conserve materials for future use. By installing a filtration system, the dust can be controlled. Even it also helps to prevent respiratory issues in employees. By placing an exhaust in large industries will help to reduce the amount of emissions that are released into the air. This includes controlling carbon monoxide and soot that is produced from low sulphur diesel. The development and improvement of waste management is another environmentally friendly process that improves the reputation of the business. And, finally, using renewable resources is a great way to become more environmentally responsible because it reduces the negative impact on the environment.

\section{Literature Review}

Milad Abdelnabi Salem (2011) has observed that "Corporate Environmental Responsibility is the duty of the corporation to mitigate its impacts on the natural environment, the implementation of such duties is known as an environmental management, which refer to the technical and organizational activities undertaken by the corporation for the purpose of reducing their environmental impacts on natural environment, while corporate environmental performance refers to the level of harmful environmental impact caused by a firm so that the smaller the harmful environmental impact the better the environmental performance and vice versa. Moreover, the corporate environmental performance can represent different levels of environmental related activities in the corporations. These levels are the operational, managerial, and conditional levels. The ecoefficiency concept incorporates the main environmental performance indicators such as clean production, pollution prevention, and waste minimization.

Piotr Mazurkiewicz (2003) has identified that "Governments have assumed principal responsibility for assuring environmental management, and have focused on creating and preserving a safe environment. They have directed the private sector to adopt environmentally sound behavior through regulations, sanctions and occasionally, incentives. When environmental problems have arisen, the public sector has generally born the responsibility for mitigation of environmental damage. In this approach, some have contended that unrestricted private sector behavior has been considered as presenting the environmental problem". 
Martin Perry and Sanjeev Singh (2001) have observed that "During the 1990s, voluntary selfregulation was promoted as a viable way of increasing business contributions to sustainable development. It was championed for its flexibility in addressing environmental issues and for the incentives it provided for environmental innovations, compared with compliance to uniform regulatory standards. Voluntarism became a popular idea among some international and government agencies, which came to see environmental regulations as stifling of industry competitiveness, costly to society and unhelpful to improving environmental performance".

\section{Company Profile}

Toyota Motor Corporation is an automaker in the Aichi region of Japan. It employs 317,734 people worldwide. The company was founded in 1937 by Kiichiro Toyoda.

Toyota started its operations in India in 1997. It invested Rs. Seven billion in the company. The Toyota Motor Company has $89 \%$ of equity shares and the Kirloskar Group has $11 \%$ equity shares in Toyota Kirloskar Motor Company. Toyota is a Japanese company while Kirloskar is an Indian Company. Toyota has global sales of 8,152,884 in Japan, 8,771,495 in Europe, 3,346,013 in Asia and 1,707,742 in other parts of the world.

In 2010 in the Canada market Toyota has sales of 172,000 vehicles, in the U.S.A of 1763000 vehicles, in Argentina of 32,000 vehicles, in Brazil 99500 vehicles, in Mexico of 47,000 vehicles, of Venezuela of 18400 vehicles, and Europe of 785000 vehicles. In South Africa of 98,000 vehicles, in China 857000 , in Taiwan 101700, in India 74500 vehicles, in Indonesia, 281000, in Malaysia, 92,000, in Pakistan 47400, in Philippines 57000 , in Thailand, 326000, in Australia 221000 vehicles.

\section{Company History}

Sakichi Toyoda invented Japan's first power loom, revolutionizing the country's textile industry. In 1924, he created the Toyoda Spinning and Weaving Company, and with the help of his son, Kiichiro Toyoda, Sakichi built an automatic loom.

In 1926, Toyoda Automatic Loom Works was created. Kiichiro was also an innovator, and visits he made to Europe and the USA in the 1920s introduced him to the automotive industry. Sakichi Toyoda received the $£ 100,000$ for selling the patent rights of his automatic loom, and Kiichiro laid the foundations of Toyota Motor Corporation in 1937.Toyota Production System was established. Kiichiro's "just- in-time" philosophy, produced only precise quantities of already ordered items with the absolute minimum of waste - was a key factor in the system's development. The Toyota Production System began to be adopted by the automotive industry across the world.

Toyota has a 40\% market share in Japan. The first Crown models arrived in the USA in 1957, and by 1965, with models such as the Corolla, Toyota began to build its reputation and sales to rival those of domestic producers. Toyota was imported into Europe was through Denmark in 1963. Toyota has continued to grow in Europe's sophisticated and complex market, and in 2000 the company delivered its ten millionth cars to a customer in Germany.

\subsection{Key milestones of Toyota in India}

It is initiated as a successful joint venture between the Japanese Toyota Motor Corporation and the Indian Kirloskar group. Toyota Kirloskar Motor (TKM) has emerged as a key player in the automobile industry over the past decade. Toyota Kirloskar Motor took off in India with humble beginnings in the Multi-Purpose Vehicle segment and within a decade has diversified into the midrange luxury and Sport Utility Vehicle segments. As a first of its kind venture by Toyota, TKM has started the manufacture of Toyota's small car in India. The following are the milestone status of Toyota in India:

- In 1997 August - Establishment of Toyota Kirloskar Motor

- In 1999 December - Qualis production started

- In 2001 April - ISO 14001 certification attained

- In 2003 January $\quad$ - Corolla production started

- In 2005 February - Innova production started

- In 2007 August _ - TITI Inauguration

- In 2009 June - Celebrated afforestration day

- In 2009 August - Launched Fortuner

- In 2010 December - Launched Prius and Etios in India.

4.2Toyota Guiding Principles

Toyota's guiding principles, which were adopted in 1992, define the mission of Toyota and the value the company delivers to stakeholders. The following are its principles: 
- Honor the language and spirit of the law of every nation and undertake open and fair business activities to be a good corporate citizen of the world.

- Respect the culture and customs of every nation and contribute to economic and social development through corporate activities in their respective communities.

- Dedicate our business to providing clean and safe products and to enhancing the quality of life everywhere through all of our activities.

- Create and develop advanced technologies and provide outstanding products and services that fulfill the needs of customers worldwide.

- Foster a corporate culture that enhances both individual creativity and the value of teamwork, while honoring mutual trust and respect between labor and management.

- Pursue growth through harmony with the global community via innovative management.

- Work with business partners in research and manufacture to achieve stable, long-term growth and mutual benefits, while keeping ourselves open to new partnerships.

4.3 Awards and Recognition

Toyota has won the following awards:

- NDTV Car and Bike Awards 2011- the Ista Green Award for the Prius and the Sub compact Sedan of the year for the Etios.

- The Subros Car and Bike India Awards 2011 - the Engine of the year and for the Altis Diesel and the Green Technology of the year for the Prius.

- The Auto India Award for the Best Brand Awards 2011 - Toyota, and Most Eco friendly award for Toyota.

- The Over Drive CNBC TV 18 Awards 2011 for the Car of the Year - Toyota Etios, the Midsize Car of the year by Toyota for Etios, the Green award of the year for Prius.

- The Bloomberg UTV Auto Car Award 2011 for the Saloon car of the year 2011 - Etios, the Green Award of the year for the Prius.

- Toyota won the Auto Build - Green Steering Wheel 2010 award for Prius, the consumer favorite large family car 2010 for the Innova, the consumer favorite enthusiast focused car 2010 for the fortuner, the consumer favorite off road 2010 for the fortuner.

- The ET Zigwheels Awards 2010 - the Car market of the year for the TKM and the Green car of the year for the Prius.

\section{Environment Performance Management}

With the aim of operating in harmony with nature, Toyota Kirloskar Motor aims to utilize resources wisely and reduce waste from its operations. Even, they have reported the resource utilization and waste generation data in their annual sustainability publications. To guide the actions in this direction the TKM Environment policy commits to control pollution and reduce energy at every possible opportunity. They continuously strived to minimize the carbon footprint and improve the environment. The periodic review by the way of internal and external audits promotes the environment management system to be more strengthened.

\subsection{Production Trends and Environment}

The market condition for Toyota vehicles in the Indian automobile sector shows a positive increment trend which consistent of the global and local automobile markets. This has a direct influence on environment performance parameters as they are related to fix manufacturing demands. During the reporting period, the production volumes showed an upward trend representing an increase in resource consumption in terms of increased energy and resource use and an increase in waste generation. During the period, the production trends show a marginal increase due to the addition of the new small car, Etios in the newly commissioned plant. TKM intends to ramp up the production volumes while minimizing environmental impact.

Table 1: Overall Production Trends

\begin{tabular}{|c|c|}
\hline Year & Production (veh/year) \\
\hline $2008-09$ & 46251 \\
\hline $2009-10$ & 63269 \\
\hline $2010-11$ & 75099 \\
\hline
\end{tabular}

\subsection{Resource consumption efficiency}

Energy and resource conservation form the basic responsibility of any corporate aspiring to be sustainable. Balancing the ever increasing consumption of resources and the consequent $\mathrm{CO}_{2}$ emissions with economic development is a major hurdle towards achieving environmental sustainability. TKM promotes energy 
conservation activities at the manufacturing plant by embracing the five year action plan which sets the annual reduction targets for all environment parameters.

TKM's electricity consumption in the production area has decreased as compared to last year. By the end of 2010, the average amount of energy required to produce a vehicle decreased by 8.3 percent to 493 kilo Watt hour (kWh) per vehicle. In 2010-11, TKM focused on energy saving activities along with optimum plant capacity utilization.

Table 2: Electricity

\begin{tabular}{|c|c|}
\hline Year & Electricity $(\mathbf{k W h} / \mathbf{v e h})$ \\
\hline $2008-09$ & 701 \\
\hline $2009-10$ & 538 \\
\hline $2010-11$ & 493 \\
\hline
\end{tabular}

\subsection{Water}

During the reporting period, the specific water consumption for production decreased by 12 percent as compared to the previous year, to reach a minimum of $2.9 \mathrm{~m} 3$ per vehicle. Water usage levels, like those for energy, were affected by the increase in production volume .Considerable efforts were made towards monitoring and standardizing variable and fixed load consumption. TKM continued to target the elimination of unnecessary water usage through kaizen and by the implementation of best process technology such as membrane bioreactor (MBR) and Reverse Osmosis (RO) treatments that allow the recycling of wastewater.

The process of treated waste water recycling for production processes has been in place at Toyota Kirloskar Motors. The recycling process employs a membrane bio-reactor [MBR] and a reverse osmosis unit. In a unique effort, emphasis is made on segregating the waste streams from the source based on strength of the waste water and to treat them accordingly. This has ensured that there are no fluctuations during treatment and treated waters are well compliant to disposal requirements. We also ensure that water use for operations does not affect water sources adversely.

Table 3: Water consumption

\begin{tabular}{|c|c|}
\hline Year & Water $\left(\mathbf{m}^{\mathbf{3}} / \mathbf{v e h}\right)$ \\
\hline $2008-09$ & 4.03 \\
\hline $2009-10$ & 3.3 \\
\hline $2010-11$ & 2.9 \\
\hline
\end{tabular}

\subsection{Steel}

Steel forms the major raw material used in the automobile industry. A car's body has to be the epitome of safety, stability, durability and consistency. Steel usage also has an environment impact, particularly with respect to resource consumption and global warming.

Steel has been a very substantial raw material for the passenger car automobile industry where it constitutes up to 23 percent of the weight of the final finished product. The use of steel at TKM begins with decoiling and cutting processes, both of which are carried out by an on-site supplier. TKM's objective in reducing Steel wastage is to reduce the carbon footprint from steel manufacturing. They conducted an in-house study, it reveals that the steel yield ratio has been increased and 180 tones on steel are reused and a significant reduction in $\mathrm{CO}_{2}$ emissions have seen.

Table 4: Steel Yield Ratio

\begin{tabular}{|c|c|}
\hline Year & Steel Yield Ratio (\%) \\
\hline $2008-09$ & 69.53 \\
\hline $2009-10$ & 70.17 \\
\hline $2010-11$ & 71.83 \\
\hline
\end{tabular}

\subsection{Liquefied Petroleum Gas}

Liquefied Petroleum Gas (LPG) serves as the prominent primary energy source for heating in ovens and boilers at TKM. Optimization of oven start-up and shut down has been one of the path-breaking improvements that were taken up during the reporting period. Though they do not employ any renewable 
Corporate Environmental Responsibility with special reference to Toyota Motor Corporation sources of energy, they have processes and work cultures in place to ensure maximum possible reduction of energy use.

Table 5: LPG Consumption

\begin{tabular}{|c|c|}
\hline Year & LPG $(\mathbf{k g} / \mathbf{v e h})$ \\
\hline $2008-09$ & 29.80 \\
\hline $2009-10$ & 28.97 \\
\hline $2010-11$ & 25.94 \\
\hline
\end{tabular}

5.6 Emission Reduction- Volatile Organic Compounds

While there is no mandatory legislation for mitigation of Volatile Organic Compounds emissions, it has been a part of Toyota's global environment policy to reduce VOC emission from the painting process. With this end in view, they have introduced waterborne paint technology at the new production facility. Further, the use of regenerative thermal oxidizers (RTO) ensures destruction of VOCs emitted from painting operations

Table 6: Volatile Organic Compounds Emission

\begin{tabular}{|c|c|}
\hline Year & VOC $\left(\mathbf{g m} / \mathbf{m}^{\mathbf{2}}\right)$ \\
\hline $2008-09$ & 45.1 \\
\hline $2009-10$ & 43.2 \\
\hline $2010-11$ & 41.0 \\
\hline
\end{tabular}

\subsection{Waste Minimization}

TKM has resolved not to add to the growing global quantities of waste through reduction and recycling of waste material. They aim to achieve zero hazardous waste to landfill consistent with the Toyota earth charter. They have been sending hazardous wastes to co-process at the cement plant to realize the philosophy of 'zero hazardous waste to landfill'.

Other initiatives towards hazardous waste reduction include the establishment of a solar drying facility to reduce excess moisture content in hazardous wastes. There has been an increase in the non-hazardous waste quantity resulting from the introduction of a new production facility and a new model. With the introduction of the Etios, the packing material waste contributed to the increase in non-hazardous waste. They strictly comply with the legal requirements restricting trans-boundary movement of hazardous wastes. TKM also has no history of accidental spills or has had any action taken against it for non-compliance with environmental laws and regulations.

Table 7: Waste Generation Trend

\begin{tabular}{|c|c|c|}
\hline \multirow{2}{*}{ Year } & \multicolumn{2}{|c|}{ Waste (kg/veh) } \\
\cline { 2 - 3 } & Hazardous waste & Non-hazardous waste \\
\hline $2008-09$ & 8.0 & 14.5 \\
\hline $2009-10$ & 5.9 & 16.7 \\
\hline $2010-11$ & 7.2 & 25.2 \\
\hline
\end{tabular}

5.8 TKM Five year Environment Action Plan

TKM's Environment Committee in the course of planning and managing the organization's environment performance has been implementing the five year plans since inception. These five year action plans are intended to serve as guidelines for all activities from an environment perspective. The following table gives details of the various action items and goals and performance data for the reporting period.

Table 8: Five year Environment Action plan

\begin{tabular}{|c|c|c|c|}
\hline Action Item & Specific action item and goals & \multicolumn{2}{|c|}{$\begin{array}{c}5 \text { year action plan status } \\
\text { F.Y } 2010\end{array}$} \\
\hline & Production: & Target & Actual \\
\hline & Energy Reduction & $4 \%$ & $4 \%$ \\
\hline Reduce $\mathrm{CO}_{2}$ & $\begin{array}{l}\text { Reduction in electricity } \\
\text { consumption(purchase+generated) } \\
\text { (kwh/veh) 20\% Current year }\end{array}$ & $512 \mathrm{kwh} / \mathrm{veh}$ & $493 \mathrm{kwh} / \mathrm{veh}$ \\
\hline
\end{tabular}


Corporate Environmental Responsibility with special reference to Toyota Motor Corporation

\begin{tabular}{|c|c|c|c|}
\hline \multirow{5}{*}{$\begin{array}{l}\text { emissions in } \\
\text { production and } \\
\text { logistics activities } \\
\text { of each country and } \\
\text { region }\end{array}$} & status. & & \\
\hline & $\begin{array}{l}\text { Reduction in LPG consumption. } \\
\text { (kg/veh) } 20 \% \text { Current year status. }\end{array}$ & $27.84 \mathrm{~kg} / \mathrm{veh}$ & $25.91 \mathrm{~kg} / \mathrm{veh}$ \\
\hline & $\begin{array}{l}\text { Reduction in energy. (Total of } \\
\text { Electricity +LPG in GJ/veh) 20\% } \\
\text { based on Current year status. }\end{array}$ & $3.22 \mathrm{GJ} / \mathrm{veh}$ & $3.1 \mathrm{GJ} / \mathrm{veh}$ \\
\hline & Logistics : & & \\
\hline & $\begin{array}{l}\text { Reduction in emission of } \mathrm{CO} 2 \\
\text { /unit } 15 \% \text { reduction based on } \\
2006 \text { values }\end{array}$ & 0.55 ton/veh & 0.54 ton/veh \\
\hline \multirow{8}{*}{$\begin{array}{l}\text { Promote the } \\
\text { effective use of } \\
\text { resources to further } \\
\text { contribute to the } \\
\text { realization of a } \\
\text { recycling based } \\
\text { society }\end{array}$} & Production: & & \\
\hline & Increase Yield ratio & $69 \%$ & $71.8 \%$ \\
\hline & Hazard Waste reduction & $4 \%$ & $4 \%$ \\
\hline & $\begin{array}{l}\text { Reduction in generation of } \\
\text { Hazardous waste (kg/veh). } 20 \% \\
\text { based on Current year status } \\
\text { Chemical sludge+ Phosphate } \\
\text { sludge +Paint sludge) }\end{array}$ & $7.6 \mathrm{kgs} / \mathrm{veh}$ & $7.03 \mathrm{kgs} / \mathrm{veh}$ \\
\hline & Non-Hazardous Waste Reduction & $2 \%$ & $2 \%$ \\
\hline & $\begin{array}{l}\text { Reduction in generation of Non } \\
\text { Hazardous waste (Miscellaneous } \\
\text { solid waste) by } 20 \% \text { based on } \\
\text { Current year status }\end{array}$ & $14.41 \mathrm{kgs} / \mathrm{veh}$ & $25.51 \mathrm{kgs} / \mathrm{veh}$ \\
\hline & Logistics : & & \\
\hline & $\begin{array}{l}\text { Reduction of packaging and } \\
\text { wrapping Materials }\end{array}$ & \multicolumn{2}{|c|}{$\begin{array}{l}\text { 100\% returnable packaging for } \\
\text { all } \\
\text { local parts }\end{array}$} \\
\hline \multirow{2}{*}{$\begin{array}{l}\text { Initiatives to } \\
\text { promote } \\
\text { water conservation }\end{array}$} & \multirow{2}{*}{$\begin{array}{l}\text { Reduction of water consumption } \\
\text { by } 10 \% \text { based on current year } \\
\text { status (m3/veh) }\end{array}$} & $2 \%$ & $2 \%$ \\
\hline & & $4.46 \mathrm{~m} 3 / \mathrm{veh}$ & $3.9 \mathrm{~m} 3 / \mathrm{veh}$ \\
\hline $\begin{array}{l}\text { Initiative to reduce } \\
\text { VOC emissions }\end{array}$ & VOC reduction & $48.5 \mathrm{gm} / \mathrm{m} 2$ & $41.6 \mathrm{gm} / \mathrm{m} 2$ \\
\hline
\end{tabular}

\section{Environment Initiatives}

The following are the various environmental initiatives taken up by Toyota Kirloskar Motors:

\subsection{Green Purchase Guidelines}

Comprehensive environmental management means looking beyond the boundaries of the own operations to the wider supply chain. TKM has adopted the 'Green Purchasing Guidelines' policy which includes the environmental criteria in every purchasing decision that encourages their suppliers to improve their environmental performance. In addition to meeting traditional expectations of quality, service and price they are giving preference to suppliers and products with better social and environmental credentials.

\subsection{Reduction in the use of Substances of Environmental Concern}

Toyota's global standard promotes the elimination of substances of environment concern. Hexavalent Chromium, Cadmium, Lead and Mercury have been eliminated from almost all parts of the Innova, Corolla and Fortuner at TKM. Although, there is no requirement or law regarding the end of a vehicle's life in India, but TKM have proactively taken up in early elimination. This aims at creating a better and safe environment for the future generations.

\subsection{Acquisition of ISO 14001Certification}

Toyota Kirloskar Motor undertakes the systematic management of environmental preservation activities and works to continuously improve them. TKM requests that all suppliers create the systems necessary to carry out environmental preservation activities and constantly improve them. To do this suppliers are requested to acquire the ISO 14001 certification. 
6.4 Environmental initiatives related to suppliers business activities

In addition to the initiatives taken by Toyota Motor Corporation, Toyota Kirloskar Motor (TKM) has set ambitious targets to work on various environmental improvement activities. Suppliers delivering parts, raw materials and supplementary materials should also take an active approach to environmental initiatives as a part of their business activities.

- Compliance with environmental laws and regulations

- Enhancement of environmental performance.

6.5 Reduction of $\mathrm{CO} 2$ emissions and the use of packing and wrapping materials in logistics

The transportation of goods results in the consumption of energy and reducing this consumption of energy becomes a major issue. Thus, TKM undertakes active measures to reduce CO2 emissions (energy consumption) in logistics. TKM is also working to reduce the use of packaging and wrapping materials. The suppliers involved are also requested to implement environmental measures in their logistic activities.

\section{Benefits to Environment}

Toyota Motor Corporation is providing enormous benefits for the safety of environment. The following are the some of its benefits:

\subsection{Reducing $\mathrm{CO}_{2}$ Emissions}

Since approximately $20 \%$ of the world's total $\mathrm{CO}_{2}$ emissions from energy sources are generated by the transportation sector, reducing $\mathrm{CO}_{2}$ emissions is an extremely important issue that the automobile industry must address. Toyota considers responses to help prevent global warming to be a priority management issue and is implementing measures to reduce $\mathrm{CO}_{2}$ emissions by restricting energy consumption in all areas of business activities and all stages of vehicle development and design, production, logistics and sales.

\subsection{Eco-Vehicle Assessment System}

Ever since TMC's (Toyota Motor Corporation) in-house Research \& Development facilities acquired ISO14001 certification in 1998, the company has been constantly monitoring its progress toward achieving environmental impact reduction targets. Eco-VAS, based on the concept of Life Cycle Assessment (LCA), will serve as a valuable environment-management tool for those responsible for vehicle development.

\subsection{Fuel Cell Technology}

Fuel Cell vehicle are powered by fuel cells, which generate electricity from hydrogen, which is not only environmentally friendly and highly energy-efficient, but can also be produced using a variety of readily available raw materials. Fuel cell vehicles are ideal for achieving sustainable mobility. Therefore, Toyota is now started to implement this technology.

7.4 Improving Air quality

Improving atmospheric quality will require measures that address both stationary sources of atmospheric pollution plants and mobile sources like automobiles. Advances in technologies used in cleaning automobile exhaust emissions, including catalytic converters and air-fuel ratio compensation systems, have reduced automobile emissions. Toyota motors are reducing emissions to improve urban air quality and reducing VOC emissions and developing low emissions technologies and introducing low emissions vehicles according to the local conditions in various countries.

7.5 Preventing Global Warming

$\mathrm{CO}_{2}$ traps solar heat, and proper quantities of $\mathrm{CO}_{2}$ keep the earth at a comfortable temperature as a greenhouse gas. If too much $\mathrm{CO}_{2}$ is emitted, it will cover the earth like a greenhouse and temperatures will rise. It is very important to make efforts toward reduction of $\mathrm{CO}_{2}$ to prevent global problems. In a study in Japan has revealed that transportation category alone producing most of the $\mathrm{CO}_{2}$ emissions. Out of it $50 \%$ are from passenger cars.

\section{Fig. 1: Emission of $\mathrm{CO}_{2}$ in Transportation and in passenger cars}

- Ratio of emission of $\mathrm{CO}_{2}$ in transportation category

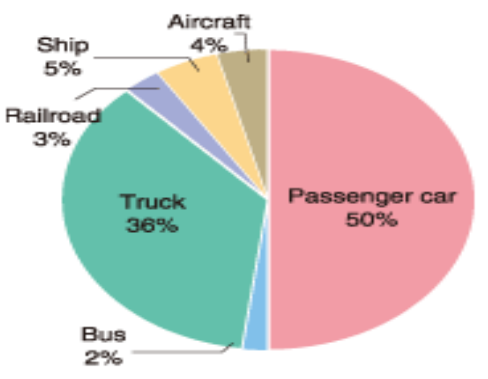

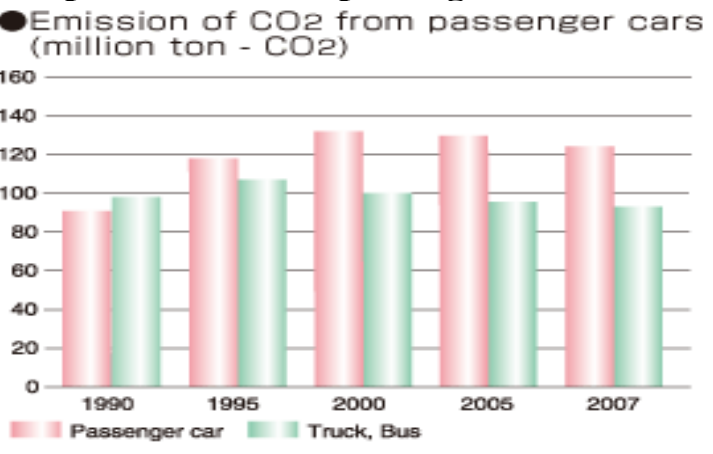


Adapted from database on greenhouse gas emissions by National Institute for Environmental Studies \&

Greenhouse Gas Inventory Office of Japan (GIO).

7.6 Using Renewable Energy

Toyota introduced renewable energy, taking into consideration the regional characteristics of each of its plant. A photovoltaic generation system has been installed and has a rated output of 2,000 kW, the world's highest level for an automobile production plant. When compared to a thermal power plant, the system results in a reduction in crude oil consumption of approximately 500 kilolitres (equal to about 2,500 200-liter drums) annually.

\section{Findings of the Study}

From the above discussions the following findings have been derived:

i. The Toyota Kirloskar Motors are successfully undertaking the environmental protection issues through their prevention techniques in their organization.

ii. The water conservation is very essential in any organization now-a-days. At TKM in order to utilize the treated water effectively, measures like re-use in toilets, irrigation of mass afforestration project and gardening are undertaken.

iii. Due to inadequacy of power supply problem of today, TKM has making a better utilization of energy. Owing to the variable requirements of the wastewater flow and oxygen requirements, the implementation of Variable frequency drives has yielded excellent results in power saving techniques.

iv. The waste reductions are effectively done by reducing the ply of packaging material in TKM is a popular mode.

v. The reuse facility of Toyota in Steel reduces the emission of $\mathrm{CO}_{2}$ and thus leads to the prevention of global warming through steel.

vi. Utilization of renewable energy in Toyota promotes optimum use of the available energy and yields a maximum output.

\section{Conclusion}

Each and every organization of today has a better knowledge about their environmental responsibility. They have realized the mere importance of their own responsibility towards the society and the environment which they survive. Being the world famous motor company Toyota has launched its footstep towards the environmental responsibility. They served in most of the environmental areas such as water conservation, prevention of carbon emission and global warming, energy conservation and in renewable sources of energy. Environmental degradation is also better taken into its consideration that reflects in the new production of greentech cars. This helps the company to gain sufficient reputation from the public. This in turn will increase its sales volume and profit. Toyota is an example for all the companies in the world in preventing the environment. Hence, if all the companies strive to put some effort to increase its responsibility towards the environment, it can surely shine in the society as Toyota Motors Limited.

\section{References}

[1] Adeena Jamal, Corporate Social responsibility and the environmental liability, Youthkiawaaz.com.

[2] Gitanjali, Corporate Social Responsibility and Environment, 16 February 2012.

[3] Lyon.T.P. \& Maxwell, J.W.2007, Corporate Social Responsibility and the environment: A Theoretical Perspective.

[4] Milad Abdelnabi Salem, Can the Eco-efficiency represent Corporate Environmental Performance, International Journal of Humanities and Social Science Voume 1, No.14, October 2011.

[5] Piotr Mazurkiewicz, Corporate Environmental Responsibility: Is a common CSR framework possible?

[6] Martin Perry and Sanjeev Singh, Corporate Environmental Responsibility in Singapore and Malaysia, Technology Business and Society Programme, Paper number 3, April 2001.

[7] Environmental Responsibilities of a Business, Monday 17, September 2012

[8] Toyota Motor Corporation, Environmental Report 2011.

[9] Toyota Quality Revolution, Toyota Kirloskar Motor, Sustainability Report 2011

[10] Toyota India, Driveindia.com. 